\title{
Study on Differentiate Procedure of Alkaline Phosphatase Test by Conventional Colorimetric Method and Optimized Standard Method in Pasteurized Milk
}

\author{
Avra Pratim Chowdhury ${ }^{1}$, Mohammad Abul Manchur ${ }^{2}$, Kazi Mohammad Rokonuddin ${ }^{3}$ \\ ${ }^{1}$ Department of Microbiology, University of Chittagong \\ ${ }^{2}$ Department of Microbiology, University of Chittagong \\ ${ }^{3}$ Surgiscope Laboratory, Chittagong.
}

\begin{abstract}
In order to determine pasteurized milk, one of the enzymes milk phosphates, is measured. A negative phosphates' result indicates that any pathogenic bacteria have been destroyed during pasteurization. If it is positive, it means the pasteurization process was inadequate and the milk may not be safe for human consumption and will have a short shelf life. In conventional method the milk samples are diluted with buffer at $\mathrm{pH} 10.2$ and incubated at the temperature at $37^{\circ} \mathrm{C}$ for $2 \mathrm{hrs}$.Any alkaline phosphates present in the milk samples will liberate Para nitro phenol from artificially added disodium p-nitrophenyle phosphate which can be compared with the standard color disc. There are differences for measuring the phosphatase activity in between conventional method and Optimized Standard Method. So Chowdhury AP ${ }^{I}$ et.al., applied "Optimized Standard Method" according to the recommendation of the German clinical chemistry association (Deutsche Gesellschaft fur Klinische Chemie, DGKC) at the purpose of showing its better performance than conventional procedure with in short time.
\end{abstract}

Keywords: Alkaline Phosphatase, Chromogenic substances, DGKC method, Mastitis Test.

Objectives: Study on differentiate Results of ALP analysis from Milk samples (Raw, Pasteurized and UHT) distinguishing between conventional method and newly applied DGKC method.

\section{Introduction}

Pasteurization is a method of Heat treating milk to improve its storage qualities and destroy pathogenic bacteria. Milk is heated to $65^{\circ} \mathrm{C}$ for 30 minutes or $72^{\circ} \mathrm{C}$ for 15 minutes followed by rapid cooling to bellow $10^{\circ} \mathrm{C}$; the method was devised by the French Microbiologist Louis Pasteur (18221895).

A simple phosphates' test is recommended to determine whether milk has been properly pasteurized or not. Milk has the alkaline Phosphatase inactivated by the time /temperature combinations applied during pasteurization. To determine about the complete pasteurization of milk if it is free from micro organisms contaminating raw milk, a chromogenic substances is added. The alkaline phosphates present in the milk will hydrolyze the substrate producing a color which can be compared to standards to determine whether the milk is acceptable or not. The pasteurized milk should have less than one coli form per $\mathrm{ml}$ and after 5 days storage at $6^{\circ} \mathrm{C}$; its count at $21^{\circ} \mathrm{C}$ should be less than $10^{5}$ $\mathrm{cfu} / \mathrm{ml}$.

When milk is pasteurized at $63^{\circ} \mathrm{C}$ for $30 \mathrm{~min}$ in batch pasteurizer or $72^{\circ} \mathrm{C}$ for 15 seconds in heat exchanger, continuous flow pasteurizers, all pathogenic bacteria destroyed, there by rendering milk safe for human consumption. Simultaneously various enzymes present in milk, and which might affect its flavor, are destroyed.

\section{Materials and Methods}

\subsection{Samples Collection}

In the present study two types of milk samples were collected - Raw milk samples were collected from 40 (forty) healthy cows of Senowara Dairy farm, Chittagong, and Pasteurized milk samples - Farm Fresh, Milk Vita, Aarong and Pran were collected from four UHT milk suppliers -

\subsection{Samples Preparation}

Raw milk of healthy cows from Senowara Dairy Farm was denoted as Sample RM1; half of the raw milk samples were pasteurized in a home pasteurizer and denoted them as RM2. Commercially pasteurized (UHT) milks - Farm Fresh, Milk Vita, Aarong and Pran were denoted as PM1, PM2, PM3 and PM4 respectively.

2.3 Screening of Raw milk Samples for Mastitis and Somatic Cells

Raw Milk samples collected from Senowara Dairy Farm were used to determine whether they were having Mastitis and somatic cells. For this purpose, milk samples were studied details. The California Mastitis Test (CMT) is a rapid, accurate, cow side test that helps to determine somatic cell counts (SCC) of raw milk from a specific cow. Los Angeles County Board of Supervisors has developed the CMT.

Volume 5 Issue 6, June 2016 www.ijsr.net 


\section{International Journal of Science and Research (IJSR) \\ ISSN (Online): 2319-7064 \\ Index Copernicus Value (2013): 6.14 | Impact Factor (2015): 6.391}

\subsubsection{California Mastitis Test (CMT)}

The test was developed to determine the presence of subclinical mastitis in raw milk sample from individual quarters. The mixture of Sodium Dodecyle Benzosulfonate $30 \mathrm{gm}$ and Bromocresol purple - $1 \mathrm{gm}$ was used as CMT reagent. Each teat of the cow was washed with alcohol prior to squire the milk. A small amount of milk sample (approximately $1 / 2$ teaspoon) from each quarter was collected into a plastic paddle that has 4 shallow cups marked as A, B, $\mathrm{C}$ and $\mathrm{D}$. An equal amount of CMT reagent was added to the milk in each cup of the paddle. The paddle was rotated to mix the contents for approximately 10 seconds and score while continuing to rotate the paddle as the reaction disappears within 20 seconds. The test result was read quickly.

\subsubsection{Somatic cell count (SCC)}

Somatic Cell Count (SCC) is used as an indicator of the quality of raw milk (i.e., its suitability to make high-quality milk products). Somatic cells are primarily white blood cells (i.e., leukocytes). The number of somatic cells may increase as a result of udder infection (e.g., mastitis) or teat/udder injury and varies due to many factors, including the cow's age, lactation stage, season and stress.

2.3.3 Standard Results of CMT Scores (Los Angeles County Board of Supervisors)

Table1:

\begin{tabular}{|c|c|c|}
\hline $\begin{array}{c}\text { CMT } \\
\text { Score }\end{array}$ & $\begin{array}{c}\text { Avg. Somatic } \\
\text { Count (Cells / ml) }\end{array}$ & Description of reaction \\
\hline Negative & $\leq 100,000$ & No thickening, homogeneous. \\
\hline Subclinical & $\leq 300,000$ & $\begin{array}{c}\text { Slight thickening. Reaction } \\
\text { disappears in 10 seconds. }\end{array}$ \\
\hline Clinical & $\leq 900,000$ & $\begin{array}{c}\text { Distinct thickening, no gel } \\
\text { formation. }\end{array}$ \\
\hline Sub acute & $\leq 2,700,000$ & $\begin{array}{c}\text { Thickens immediately, begins to } \\
\text { gel, levels in the bottom of cup. }\end{array}$ \\
\hline Acute & $\leq 8,100,000$ & $\begin{array}{c}\text { Gel is formed, surface elevates, } \\
\text { with a central peak above mass. }\end{array}$ \\
\hline
\end{tabular}

Table 2

\begin{tabular}{|c|c|c|c|c|}
\hline Samples & CMT Score & $\begin{array}{c}\text { Avg. Somatic } \\
\text { Count }(\text { Cells } / \mathrm{ml})\end{array}$ & Standard & Description of reaction \\
\hline RM1 & Acute & $8,500,000$ & $8,100,000$ & Gel is formed, surface elevates, with a central peak above mass. \\
\hline RM2 & Subclinical & 270,985 & 300,000 & Slight thickening. Reaction disappears in 10 seconds \\
\hline RM3 & Subclinical & 278,654 & 300,000 & Slight thickening. Reaction disappears in 10 seconds \\
\hline RM4 & Subclinical & 289,765 & 300,000 & Slight thickening. Reaction disappears in 10 seconds \\
\hline RM5 & Negative & 80,794 & 100,000 & No thickening, homogeneous \\
\hline RM6 & Clinical & 897,654 & 900,000 & Distinct thickening, no gel formation. \\
\hline RM7 & Subclinical & 277,239 & 300,000 & Slight thickening. Reaction disappears in 10 seconds \\
\hline RM8 & Negative & 100,000 & 100,000 & No thickening, homogeneous \\
\hline RM9 & Acute & $8,233,456$ & $8,100,000$ & Gel is formed, surface elevates, with a central peak above mass. \\
\hline RM10 & Negative & 67,894 & 100,000 & No thickening, homogeneous \\
\hline RM11 & Negative & 87,596 & 100,000 & No thickening, homogeneous \\
\hline RM12 & Subclinical & 199,876 & 300,000 & Slight thickening. Reaction disappears in 10 seconds \\
\hline RM13 & Negative & 76,892 & 100,000 & No thickening, homogeneous \\
\hline RM14 & Negative & 84,676 & 100,000 & No thickening, homogeneous \\
\hline RM15 & Negative & 99,305 & 100,000 & No thickening, homogeneous \\
\hline RM16 & Clinical & 879,343 & 900,000 & Distinct thickening, no gel formation. \\
\hline RM17 & Sub acute & $2,657,865$ & $2,700,000$ & Thickens immediately, begins to gel, levels in the bottom of cup. \\
\hline RM18 & Sub acute & $2,776,543$ & $2,700,000$ & Thickens immediately, begins to gel, levels in the bottom of cup. \\
\hline RM19 & Negative & 99,847 & 100,000 & No thickening, homogeneous \\
\hline RM20 & Subclinical & 298,788 & 300,000 & Slight thickening. Reaction disappears in 10 seconds \\
\hline RM 21 & Sub acute & $2,567,898$ & $2,700,000$ & Thickens immediately, begins to gel, levels in the bottom of cup. \\
\hline RM22 & Sub acute & $2,665,933$ & $2,700,000$ & Thickens immediately, begins to gel, levels in the bottom of cup. \\
\hline RM23 & Subclinical & 234,660 & 300,000 & Slight thickening. Reaction disappears in 10 seconds \\
\hline RM24 & Negative & 76,543 & 100,000 & No thickening, homogeneous \\
\hline RM25 & Sub acute & $2,577,681$ & $2,700,000$ & Thickens immediately, begins to gel, levels in the bottom of cup \\
\hline RM26 & Acute & $8,245,678$ & $8,100,000$ & Gel is formed, surface elevates, with a central peak above mass. \\
\hline RM27 & Sub acute & $2,656,443$ & $2,700,000$ & Thickens immediately, begins to gel, levels in the bottom of cup. \\
\hline RM28 & Negative & 87,652 & 100,000 & No thickening, homogeneous \\
\hline RM29 & Sub acute & $2,567,768$ & $2,700,000$ & Thickens immediately, begins to gel, levels in the bottom of cup. \\
\hline RM30 & Negative & 80,765 & 100,000 & No thickening, homogeneous \\
\hline RM31 & Acute & $8,123,987$ & $8,100,000$ & Gel is formed, surface elevates, with a central peak above mass. \\
\hline RM32 & Subclinical & 255,632 & 300,000 & Slight thickening. Reaction disappears in 10 seconds \\
\hline RM33 & Negative & 97,654 & 100,000 & No thickening, homogeneous \\
\hline RM34 & Subclinical & 277,984 & 300,000 & Slight thickening. Reaction disappears in 10 seconds \\
\hline RM35 & Sub acute & $2,699,832$ & $2,700,000$ & Thickens immediately, begins to gel, levels in the bottom of cup. \\
\hline RM36 & Negative & 89,987 & 100,000 & No thickening, homogeneous \\
\hline RM37 & Clinical & 899,349 & 900,000 & Distinct thickening, no gel formation. \\
\hline RM38 & Sub acute & $2,633,458$ & $2,700,000$ & Thickens immediately, begins to gel, levels in the bottom of cup. \\
\hline RM39 & Negative & 65,432 & 100,000 & No thickening, homogeneous \\
\hline RM40 & Acute & $8,346,342$ & $8,100,000$ & Gel is formed, surface elevates, with a central peak above mass. \\
\hline
\end{tabular}

Volume 5 Issue 6, June 2016 www.ijsr.net

Licensed Under Creative Commons Attribution CC BY 


\section{International Journal of Science and Research (IJSR) \\ ISSN (Online): 2319-7064 \\ Index Copernicus Value (2013): 6.14 | Impact Factor (2015): 6.391}

In this method verified results were studied then mastitis negative samples denoted for rejection. Following the tested mastitis samples should to take for Pasteurization by dint of
Home Pasteurizer machine. Recommended samples should to take for Pasteurization process due to presence of Mastitis causing Microorganisms of milk.

Table 3:

\begin{tabular}{|c|c|c|}
\hline Biochemical Types & Microorganisms & Substrate acted upon \& end products \\
\hline & $\begin{array}{l}\text { Streptococcus lactis. } \\
\text { Streptococcus cremoris. } \\
\text { Lactobacillus spp. }\end{array}$ & $\begin{array}{l}\text { Lactose fermented to lactic acid and other products such as carbon } \\
\text { dioxide, ethyl alcohol, acetic acid, etc. } \\
\text { Lactose is fermented to lactic acid and other products. }\end{array}$ \\
\hline Acid Producers & $\begin{array}{l}\text { Microbacterium lactium } \\
\text { Escherichia coli } \\
\text { Enterobacter aerogenes } \\
\text { Micrococcus luteus }\end{array}$ & $\begin{array}{l}\text { Lactose is fermented to lactic acid. Heat resistant }\left(80-85^{\circ}\right) \mathrm{C} \\
\text { Lactose fermented to mixture of end products such as acid, gases, \& } \\
\text { neutral products. } \\
\text { Weakly fermentative of lactose; weakly proteolytic. Moderately heat } \\
\text { resistant }\left(60-63^{\circ}\right) \mathrm{C} \text {. }\end{array}$ \\
\hline Gas Producers & $\begin{array}{c}\text { Coliforms spp., Clostridium spp., Butyricum } \\
\text { spp.,Torula cremoris. }\end{array}$ & $\begin{array}{l}\text { Lactose fermented with accumulation of gas (mixture of carbon- di-oxide } \\
\qquad \& \text { hydrogen). }\end{array}$ \\
\hline $\begin{array}{l}\text { Ropy or Stringy } \\
\text { Fermentaters }\end{array}$ & $\begin{array}{c}\text { Alcaligenes viscolactis, Enterobacter } \\
\text { aerogenes Streptococcus cremoris }\end{array}$ & $\begin{array}{c}\text { Synthesize a viscous polysaccharide material that forms the slime layer } \\
\text { or bacterial capsule. }\end{array}$ \\
\hline Proteolytic & $\begin{array}{c}\text { Bacillus subtilis, } \text { B. cereus, } \\
\text { Pseudomonas spp., Streptococcus sp. }\end{array}$ & $\begin{array}{l}\text { Degrade casein to peptides \& amino acids. Pseudomonas may produce } \\
\text { coloration of milk. }\end{array}$ \\
\hline Lipolytic & $\begin{array}{c}\text { Pseudomonas fluorescens. } \\
\text { Achromobacter lipolyticum. } \\
\text { Candida lipolytica, Penicillium spp. }\end{array}$ & $\begin{array}{l}\text { Hydrolyze milk fat into glycerol \& fatty acids. Some fatty acid impart } \\
\text { rancid odor to the milk. }\end{array}$ \\
\hline
\end{tabular}

Every Raw milk samples (RM) were selected for pasteurization and derived as Home Pasteurized samples (HPM) .Then ALP analysis was applied in two different procedure to verify ALP values of Raw milk samples (RM), Home Pasteurized samples (HPM) and UHT samples.

\subsubsection{Phosphatase test by Conventional Colorimetric method}

In titration method equipments should be required test tubes, $5 \mathrm{ml}$ pipettes, $1 \mathrm{ml}$ pipettes, $100 \mathrm{ml}$ volumetric flask, $500 \mathrm{ml}$ volumetric flask, water bath at $37^{\circ} \mathrm{C}$. All glassware must be rinsed, cleaned, rinsed in chromic acid solution and boiled in water for $30 \mathrm{~min}$. Reagent should be prepared into two categories

Buffer solution: Is mixed by $0.75 \mathrm{~g}$ anhydrous sodium carbonate and $1.75 \mathrm{~g}$ Sodium bicarbonate in $500 \mathrm{ml}$ distilled water.

Buffer-substrate solution: Place $0.15 \mathrm{~g}$ of disodium Para nitro phenyl phosphate / P-Nitro phenyl phosphate disodium salt (C6H4NO6PNa2.6H2O, The substrate) into a clean $100 \mathrm{ml}$ measuring cylinder.

Add the buffer solution to make to $100 \mathrm{ml}$ mark. Store this buffer-substrate solution in a refrigerator and protected against light. It should not be used after one week. Prepare a fresh stock. Pipette $5 \mathrm{mls}$ buffer-substrate solution into a test tube, stopper and warm the solution in the water bath at $37^{\circ} \mathrm{C}$. Add to the test tube $1 \mathrm{ml}$ of the milk to be tested, stopper and mix well and place in water bath at $37^{\circ} \mathrm{C}$. Prepare a blank sample from boiled milk of the same type as that undergoing the test. Incubate both the test samples and the blank sample at $37^{\circ} \mathrm{C}$ for $2 \mathrm{hrs}$. After incubation, remove the tubes and mix them thoroughly. Place one sample against the blank in a Lovibond comparator using A.P.T.W. disc and rotate the disc until the color of the test sample is matched and read the disc number. The Phosphatase Test for Pasteurized Milk.

Disc Reading after incubation at $37^{\circ} \mathrm{C}$ from $2 \mathrm{hrs}$ then remarkable results can be determined by following range-

$\begin{array}{lc}\text { Properly pasteurized } & 0 \text { to } 10 \mu \mathrm{l} \\ \text { Slightly under pasteurized } & 10 \text { to } 18 \mu \mathrm{l} \\ \text { Under pasteurized } & 18 \text { to } 42 \mu \mathrm{l} \\ \text { Not pasteurized } & \text { more than } 42 \mu \mathrm{l}\end{array}$

\subsubsection{Phosphatase test by Optimized Standard Method} In the presence of magnesium and zinc ions p-Nitro phenyl phosphate is hydrolyzed by Phosphatase to form phosphate and p-Nitro phenol. The p-Nitro phenol released is proportional to the Alkaline Phosphatase activity and can be measured photometrical to determine the alkaline phosphates level presence in the milk. Colorimetric assay in accordance with a standard method followed by samples and then addition of Buffer solution (R1) and addition of buffer/substrate (R2).

$$
\text { p-Nitro phenyl phosphate }+\mathrm{H}_{2} \mathrm{O} \stackrel{\text { Alkaline phosphatase }}{\longrightarrow} \text { phosphate }+ \text { p-Nitro phenol }
$$

\section{Manual procedure for substrate start}

Wave length
Temperature
Cuvette
Zero adjustment

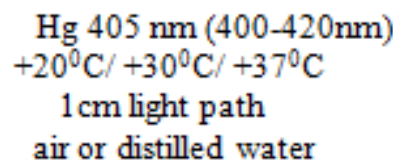

Table 4

\begin{tabular}{|c|c|c|c|}
\hline Working agent & Macro & Semi & Micro \\
\hline R1 & $2500 \mu \mathrm{l}$ & $1000 \mu \mathrm{l}$ & $500 \mu \mathrm{l}$ \\
\hline Sample & $50 \mu \mathrm{l}$ & $20 \mu \mathrm{l}$ & $10 \mu \mathrm{l}$ \\
\hline R2 & $500 \mu \mathrm{l}$ & $200 \mu \mathrm{l}$ & $100 \mu \mathrm{l}$ \\
\hline
\end{tabular}




\section{International Journal of Science and Research (IJSR) \\ ISSN (Online): 2319-7064}

Index Copernicus Value (2013): 6.14 | Impact Factor (2015): 6.391

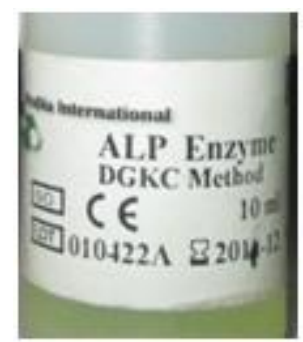

Figure 2: Reagent (R2)

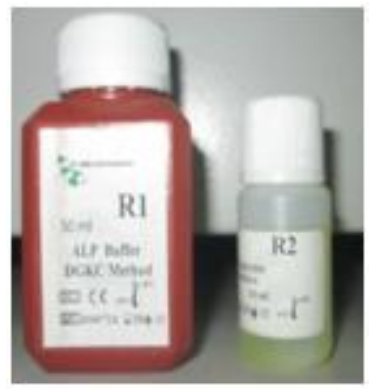

Figure 3: Buffer solution (R1) and Reagent (R2)
Clinical DGKC method is applied on pasteurized milk to determine alkaline Phosphatase level within a short time.

Reagent concentration: $\mathbf{R} \mathbf{1}$

Di ethanol amine buffer $\quad 1.0 \mathrm{~mol} / \mathrm{l}\left(\mathrm{P}^{\mathrm{H}}-9.8\right)$

Magnesium sulfates $\quad 0.6 \mathrm{~m} \mathrm{~mol} / \mathrm{l}$

Detergents and Stabilizers $>0.1 \%$

Reagent concentration: $\mathbf{R 2}$

p-Nitro phenyl phosphate $2.0 \mathrm{~m} \mathrm{~mol} / \mathrm{l}$

Stabilized, liquid $\quad 5.0 \mathrm{~g} / \mathrm{dl}$

\section{Preparation}

Centrifuge pasteurized milk sample for containing precipitate components to separate watery portion before performing the assay. $5 \mathrm{ml}$ of $\mathrm{R} 1$ are mixed with $1 \mathrm{ml}$ of $\mathrm{R} 2$.Sample is measured by $1 / 10 \mathrm{ml}$ of $\mathrm{R} 2$ and mixed with previous mixture of Reagents.

\section{Results}

Raw Milk Samples (Table5)

\begin{tabular}{|c|c|c|c|c|}
\hline Samples & \begin{tabular}{|c|} 
Conventional \\
Colorimetric method
\end{tabular} & Results & $\begin{array}{c}\text { Optimized } \\
\text { Standard Method }\end{array}$ & Results \\
\hline RM1 & more than $42 \mu \mathrm{l}$ & Discernible color & 545 & Non pasteurized \\
\hline RM2 & more than $42 \mu \mathrm{l}$ & Discernible color & 542 & Non pasteurized \\
\hline RM3 & more than $42 \mu l$ & Discernible color & 560 & Non pasteurized \\
\hline RM4 & more than $42 \mu l$ & Discernible color & 575 & Non pasteurized \\
\hline RM6 & more than $42 \mu \mathrm{l}$ & Discernible color & 623 & Non pasteurized \\
\hline RM7 & more than $42 \mu l$ & Discernible color & 685 & Non pasteurized \\
\hline RM9 & more than $42 \mu l$ & Discernible color & 430 & Non pasteurized \\
\hline RM12 & more than $42 \mu l$ & Discernible color & 580 & Non pasteurized \\
\hline RM16 & more than $42 \mu l$ & Discernible color & 560 & Non pasteurized \\
\hline RM17 & more than $42 \mu \mathrm{l}$ & Discernible color & 620 & Non pasteurized \\
\hline RM18 & more than $42 \mu \mathrm{l}$ & Discernible color & 476 & Non pasteurized \\
\hline RM20 & more than $42 \mu l$ & Discernible color & 530 & Non pasteurized \\
\hline RM21 & more than $42 \mu \mathrm{l}$ & Discernible color & 457 & Non pasteurized \\
\hline RM22 & more than $42 \mu \mathrm{l}$ & Discernible color & 278 & Non pasteurized \\
\hline RM23 & more than $42 \mu \mathrm{l}$ & Discernible color & 567 & Non pasteurized \\
\hline RM25 & more than $42 \mu \mathrm{l}$ & Discernible color & 450 & Non pasteurized \\
\hline RM26 & more than $42 \mu \mathrm{l}$ & Discernible color & 680 & Non pasteurized \\
\hline RM27 & more than $42 \mu \mathrm{l}$ & Discernible color & 372 & Non pasteurized \\
\hline RM29 & more than $42 \mu \mathrm{l}$ & Discernible color & 565 & Non pasteurized \\
\hline RM31 & more than $42 \mu l$ & Discernible color & 542 & Non pasteurized \\
\hline RM32 & more than $42 \mu \mathrm{l}$ & Discernible color & 290 & Non pasteurized \\
\hline RM34 & more than $42 \mu \mathrm{l}$ & Discernible color & 523 & Non pasteurized \\
\hline RM35 & more than $42 \mu l$ & Discernible color & 610 & Non pasteurized \\
\hline RM37 & more than $42 \mu \mathrm{l}$ & Discernible color & 624 & Non pasteurized \\
\hline RM38 & more than $42 \mu l$ & Discernible color & 578 & Non pasteurized \\
\hline RM40 & more than $42 \mu l$ & Discernible color & 348 & \\
\hline
\end{tabular}

Volume 5 Issue 6, June 2016 www.ijsr.net 
International Journal of Science and Research (IJSR)

ISSN (Online): 2319-7064

Index Copernicus Value (2013): 6.14 | Impact Factor (2015): 6.391

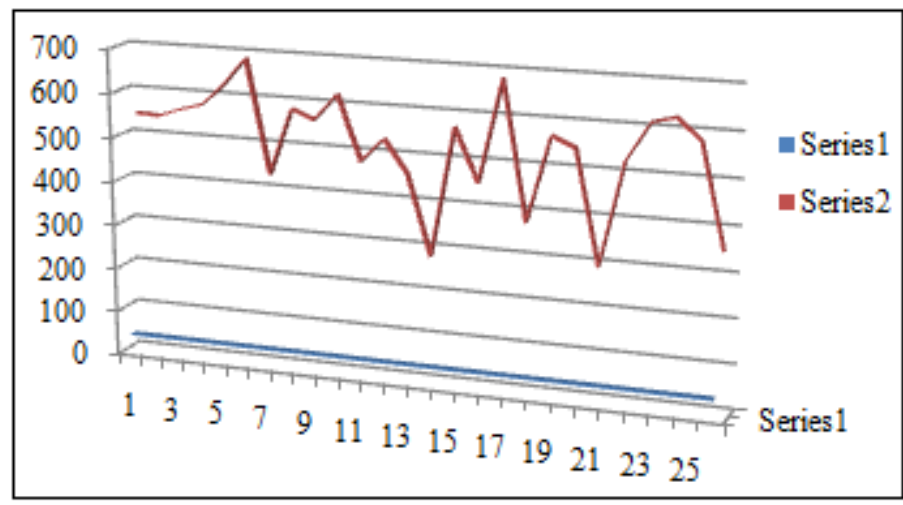

Figure 1: DGKC Method (Series2) shows high ALP values where as Conventional Method (Seres1) is parallel by a fixed value in highest range

Home Pasteurized Samples: (Table 6)

\begin{tabular}{|c|c|c|c|c|}
\hline Samples & Conventional Colorimetric method & Results & Optimized Standard Method & Results \\
\hline HPM1 & 8 & No Discernible color & 15 & Moderate pasteurized \\
\hline HPM2 & 10 & No Discernible color & 8 & Pasteurized \\
\hline HPM3 & 5 & No Discernible color & 4 & Pasteurized \\
\hline HPM4 & 7 & No Discernible color & 4 & Pasteurized \\
\hline HPM6 & 5 & No Discernible color & 2 & Pasteurized \\
\hline HPM7 & 4 & No Discernible color & 2 & Pasteurized \\
\hline HPM9 & 12 & Discernible color & 16 & Moderate pasteurized \\
\hline HPM12 & 6 & No Discernible color & 12 & Moderate pasteurized \\
\hline HPM16 & 10 & No Discernible color & 8 & Pasteurized \\
\hline HPM17 & 8 & No Discernible color & 6 & Pasteurized \\
\hline HPM18 & 10 & No Discernible color & 10 & Moderate pasteurized \\
\hline HPM20 & 14 & Discernible color & 23 & Slightly pasteurized \\
\hline HPM21 & 10 & No Discernible color & 20 & Slightly pasteurized \\
\hline HPM22 & 8 & No Discernible color & 6 & Pasteurized \\
\hline HPM23 & 10 & No Discernible color & 8 & Pasteurized \\
\hline HPM25 & 8 & Discernible color & 8 & Pasteurized \\
\hline HPM26 & 10 & No Discernible color & 5 & Pasteurized \\
\hline HPM27 & 8 & No Discernible color & 5 & Pasteurized \\
\hline HPM29 & 10 & No Discernible color & 5 & Pasteurized \\
\hline HPM31 & 5 & No Discernible color & 5 & Pasteurized \\
\hline HPM32 & 5 & No Discernible color & 4 & Pasteurized \\
\hline HPM34 & 2 & No Discernible color & 2 & Pasteurized \\
\hline HPM35 & 8 & No Discernible color & 2 & Pasteurized \\
\hline HPM37 & 7 & No Discernible color & 8 & Pasteurized \\
\hline HPM38 & 7 & No Discernible color & 2 & Pasteurized \\
\hline HPM40 & 10 & No Discernible color & 12 & Moderate pasteurized \\
\hline
\end{tabular}

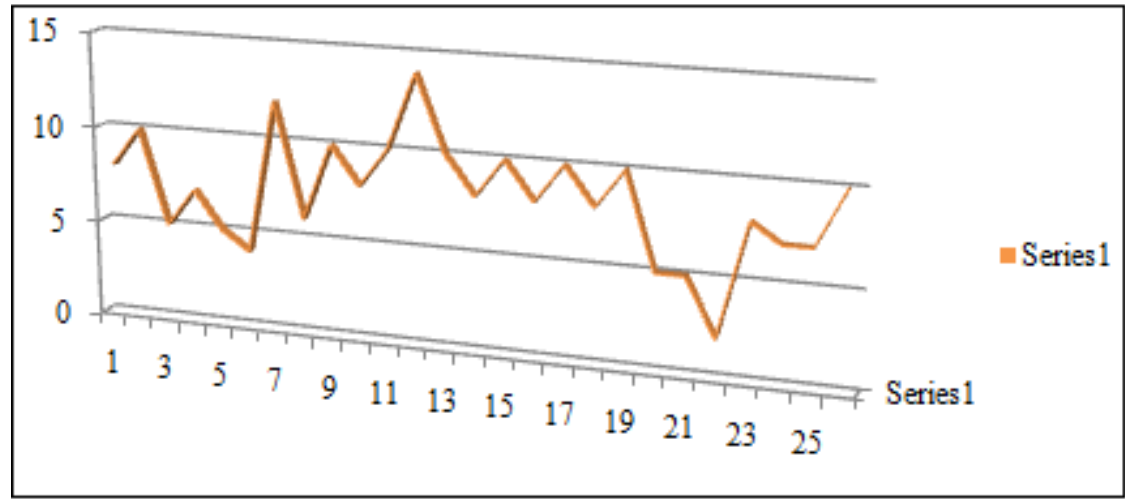

Figure 1.1: ALP values of HPM samples in Conventional Method (Seres1).

\section{Volume 5 Issue 6, June 2016} www.ijsr.net

Licensed Under Creative Commons Attribution CC BY 
International Journal of Science and Research (IJSR)

ISSN (Online): 2319-7064

Index Copernicus Value (2013): 6.14 | Impact Factor (2015): 6.391

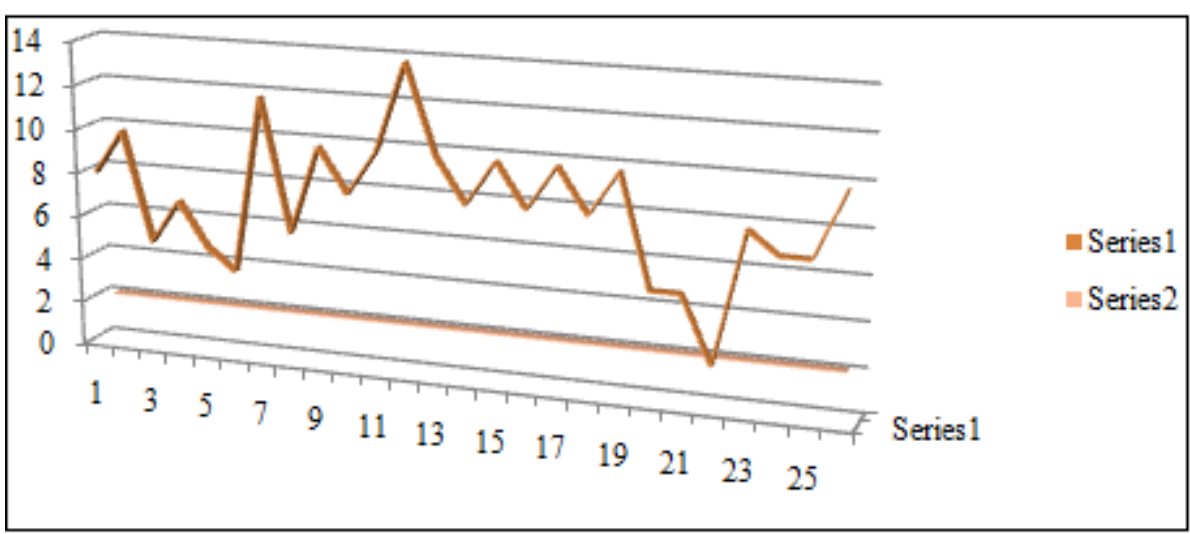

Figure 1.2: Fluctuation of ALP values in Conventional Method (Seres1) accordance with time 2hrs (Seres2)

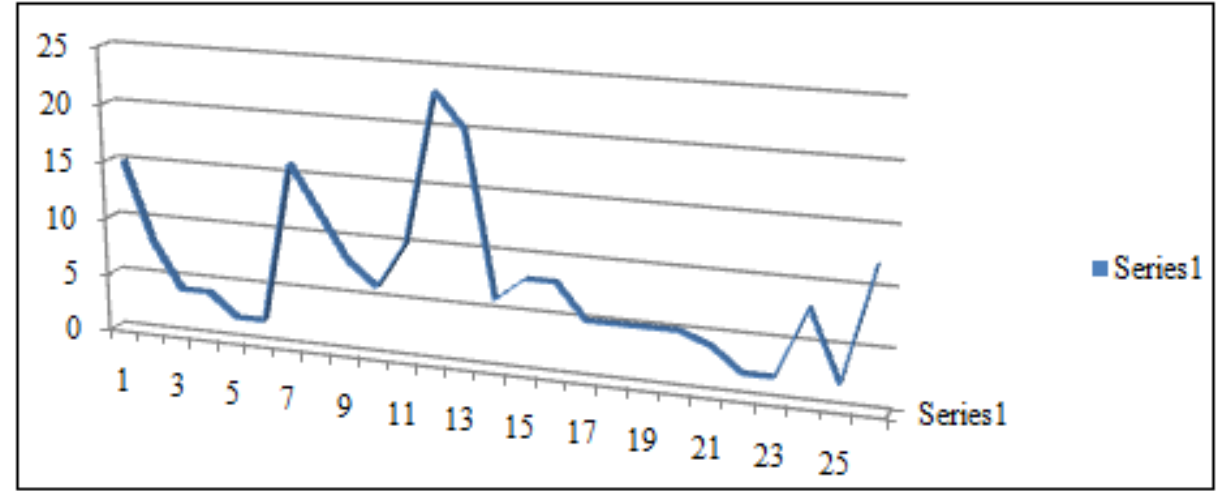

Figure 1.3: ALP values of HPM samples in Optimized Method (Seres1).

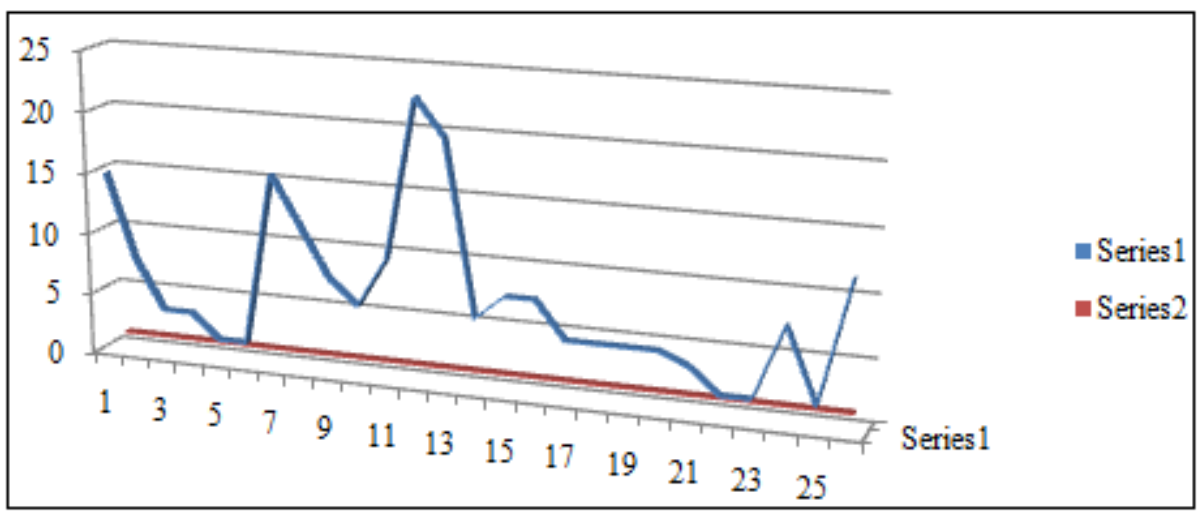

Figure 1.4: Fluctuation of ALP values in Optimized Method (Seres1) accordance with time 1hrs (Seres2)

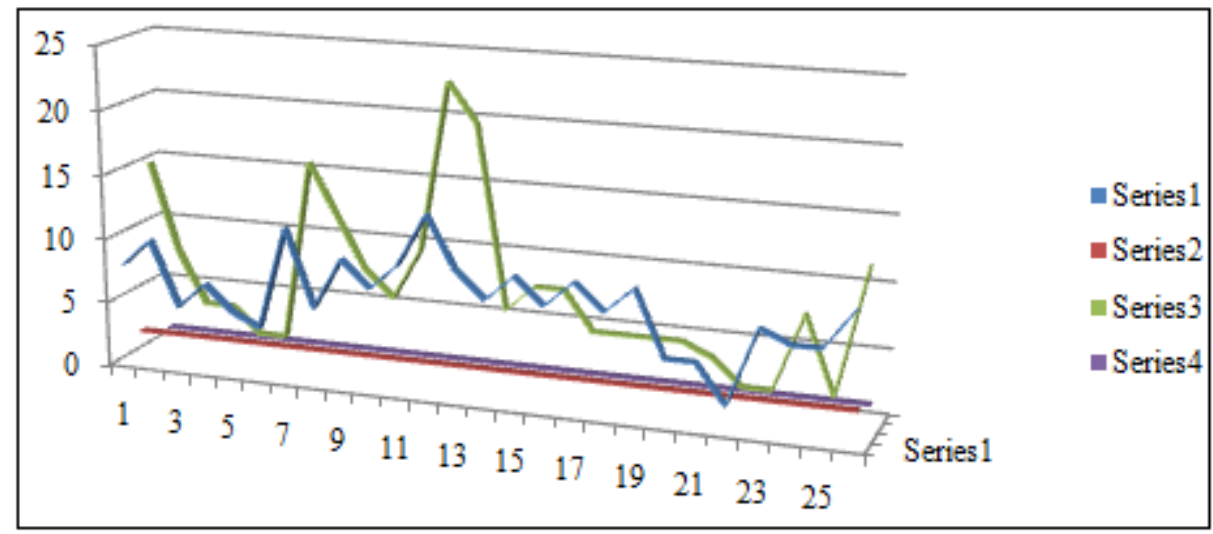

Figure 1.5: Comparative study of parameter (ALP values) in Conventional Method (Seres1) accordance with time 2hrs (Seres2) and Optimized Method (Seres3) accordance with time 1hrs (Seres4).

\section{Volume 5 Issue 6, June 2016} www.ijsr.net

Licensed Under Creative Commons Attribution CC BY 


\section{International Journal of Science and Research (IJSR) \\ ISSN (Online): 2319-7064}

Index Copernicus Value (2013): 6.14 | Impact Factor (2015): 6.391

UHT Samples: (Table7)

\begin{tabular}{|l|c|c|c|c|}
\hline Samples & $\begin{array}{c}\text { Conventional } \\
\text { Colorimetric } \\
\text { method }\end{array}$ & Results & $\begin{array}{c}\text { Optimized } \\
\text { Standard } \\
\text { Method }\end{array}$ & Results \\
\hline UHT1 & 8 & No Discernible color & 2 & Pasteurized \\
\hline UHT2 & 8 & No Discernible color & 5 & Pasteurized \\
\hline UHT3 & 5 & No Discernible color & 5 & Pasteurized \\
\hline UHT4 & 4 & No Discernible color & 2 & Pasteurized \\
\hline UHT5 & 5 & No Discernible color & 2 & Pasteurized \\
\hline
\end{tabular}

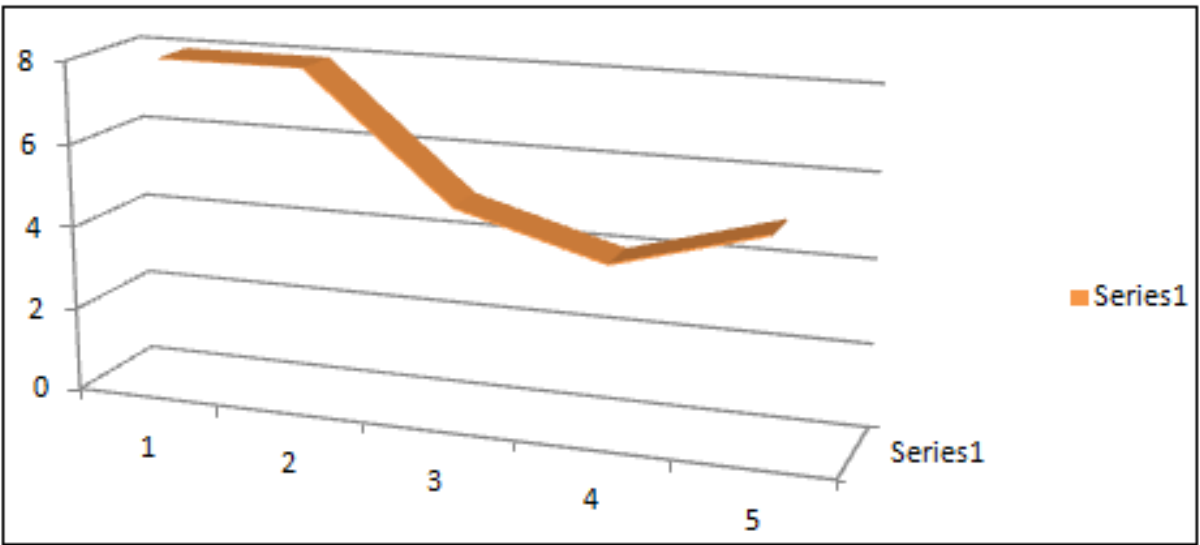

Figure 1.6: ALP values UHT samples in Conventional Method (Seres1).

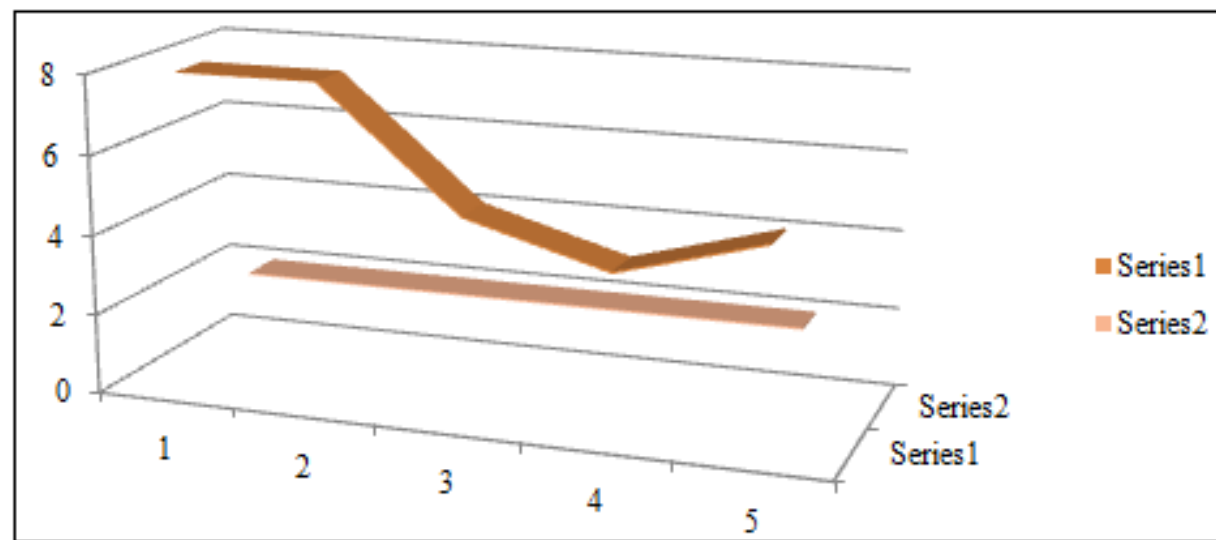

Figure 1.7: Fluctuation of ALP values in Conventional Method (Seres1) accordance with time 2hrs (Seres2)

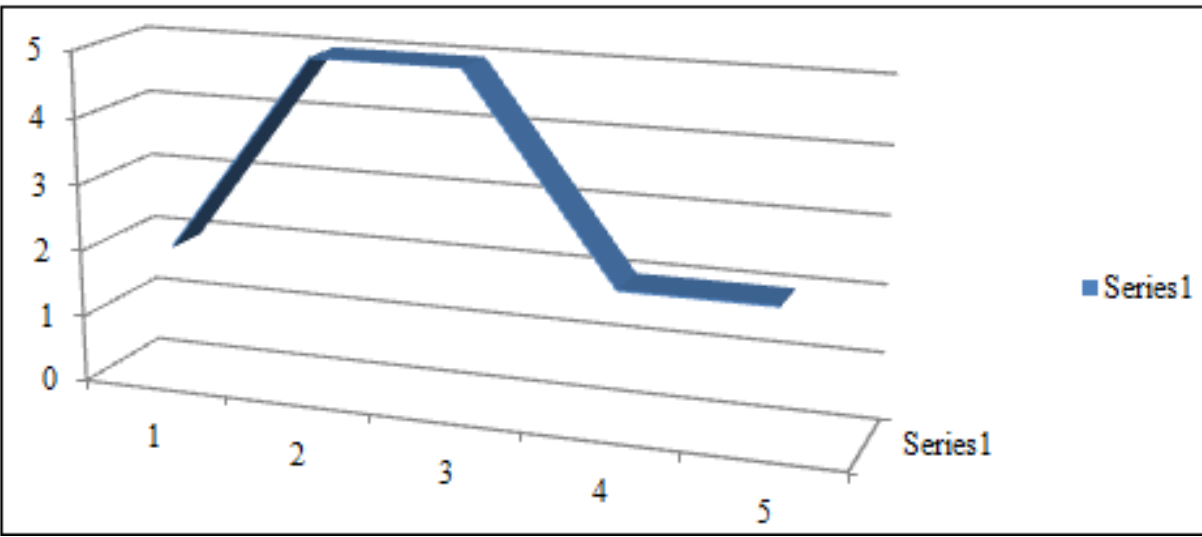

Figure 1.8: ALP values of UHT samples in Optimized Method (Seres1).

Volume 5 Issue 6, June 2016 www.ijsr.net

Licensed Under Creative Commons Attribution CC BY 
International Journal of Science and Research (IJSR)

ISSN (Online): 2319-7064

Index Copernicus Value (2013): 6.14 | Impact Factor (2015): 6.391

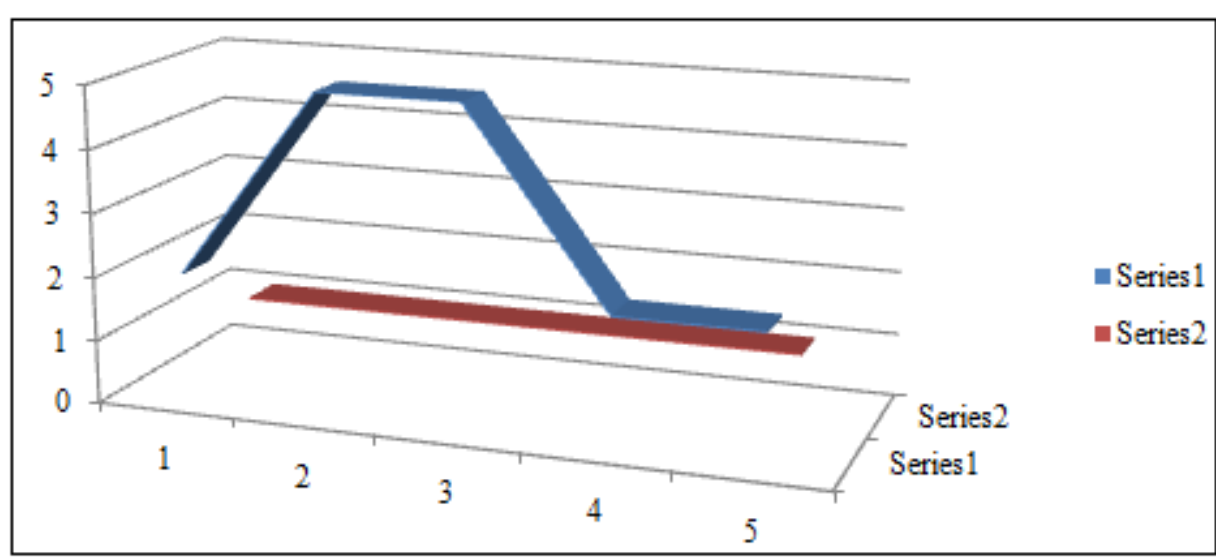

Figure 1.9: Fluctuation of ALP values in Optimized Method (Seres1) accordance with time 1hrs (Seres2)

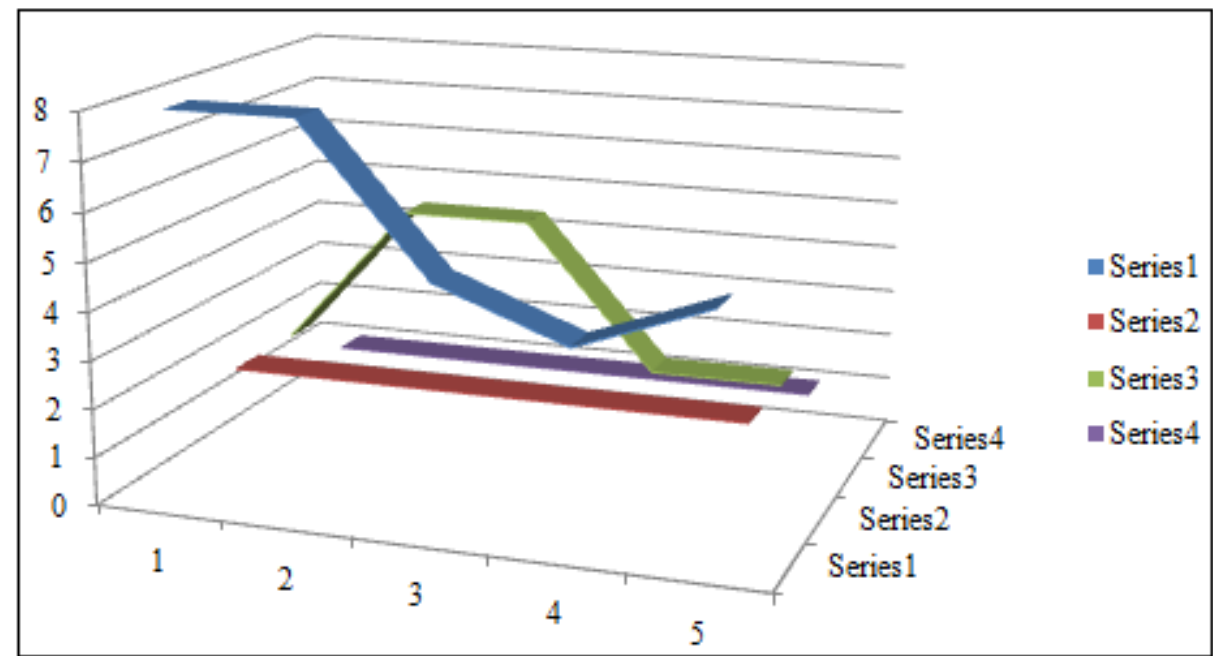

Figure 2.1: Comparative study of parameter (ALP values) in Conventional Method (Seres1) accordance with time 2hrs (Seres2) and Optimized Method (Seres3) accordance with time 1hrs (Seres4).

\section{Discussion}

Based on research findings, it should to discourage the consumption of raw milk. The risks of consuming raw milk instead of pasteurized milk are well established in the scientific literature, and in some cases can have severe or even fatal consequences. Then sample was pasteurized by home pasteurizer in our research laboratory. After pasteurization the proportion of raw milk samples (RM) was derived another samples, named Home Pasteurized Samples (HPM). DGKC Method (Series2) shows high ALP values where as Conventional Method (Seres1) is parallel by a fixed value in highest range of RM samples.

About discussing point of view in the table 5, RM samples resulted in the ALP that showing highest enzymatic degradation than table6 and table7 while future research could inform decision making on the legalization of raw milk. In between comparative study of table6 and table7 applied DGKC method is so easier procedure for perspective of ALP test. It was believed that from a public health perspective, it is a far safer choice to discourage the sale of raw milk along with Pasteurized and UHT milk without containing proper enzymatic reaction. Regardless, Milk borne harmful microbes may result the potential health risks of consuming Raw, Pasteurized and UHT milk should be clearly communicated, especially to vulnerable populations. In the beginning of research all collected samples were screened for determining the level of different values than applied for ALP analysis and graphical status showed that more fluctuation of ALP values resulted in Conventional Method (Seres1) accordance with time 2hrs (Seres2) in high level where as less fluctuation of ALP values occurred in Optimized Method (Seres1) accordance with time 1hrs (Seres2). These analytical parameter showed varifying pasteurization procedure resulted fluctuating milk components in between Conventional Method and Optimized Method. The potential benefits on the other hand, are still unclear and would benefit from further investigation. Here procedure left with a large uncertainty about the potential benefits of raw milk but with a clear understanding of the microbial hazards from consuming raw milk. So Clinical DGKC method is very much effective and accurate than Conventional method.

\section{Volume 5 Issue 6, June 2016 www.ijsr.net}




\section{International Journal of Science and Research (IJSR) \\ ISSN (Online): 2319-7064}

Index Copernicus Value (2013): 6.14 | Impact Factor (2015): 6.391
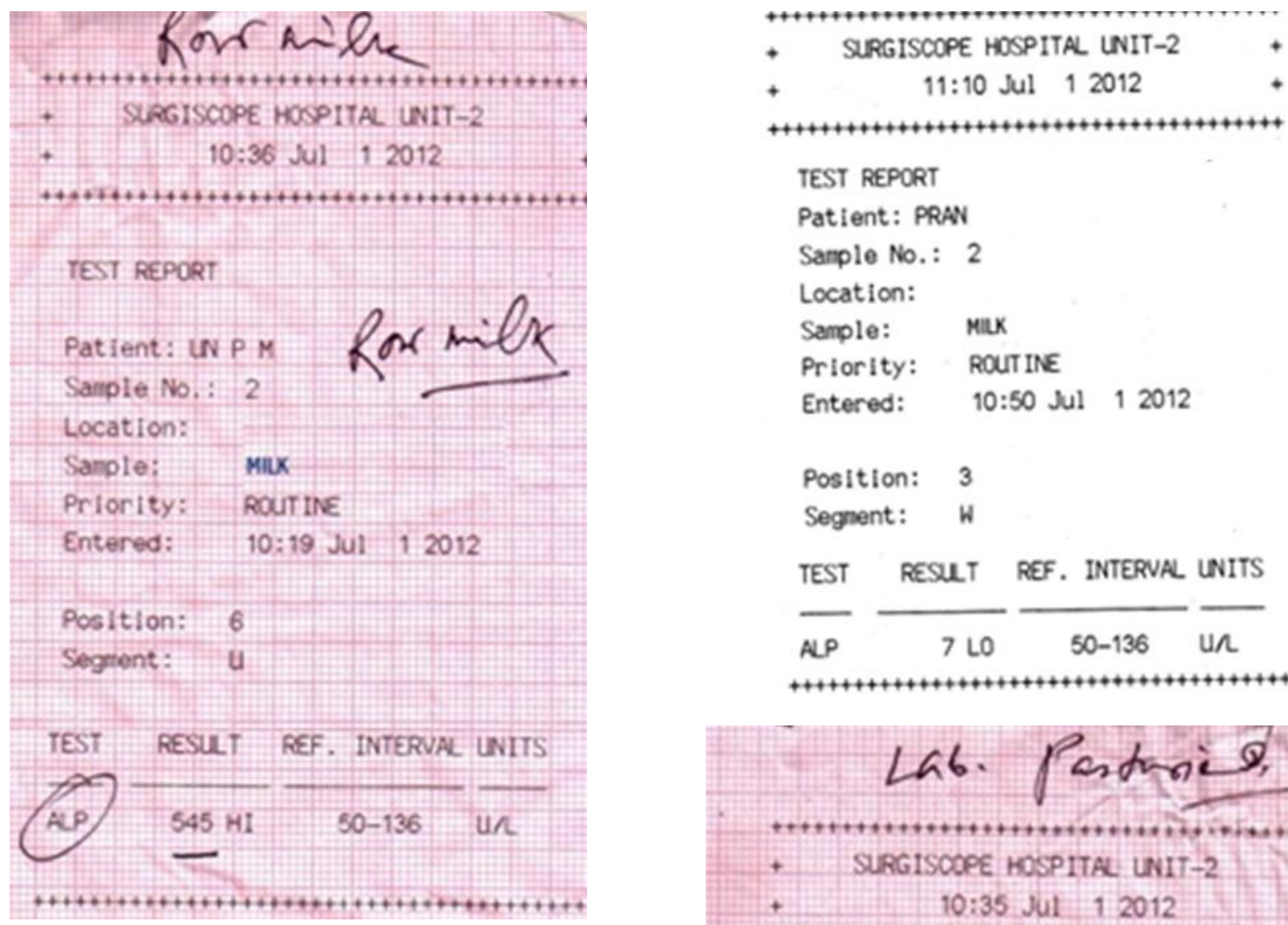

TEST REPORT

Patient: PRAN

Sample No.: 2

Location:

Sample: MIK

Prlority: ROUTINE

Entered: $\quad$ 10:50 Jul 12012

Position: 3

Segsent: W

$\frac{\text { TEST }}{\text { ALP }} \frac{\text { RESUT }}{7 \text { LO }} \frac{\text { REF. INTERVAL UNITS }}{50-136} \frac{\text { Un }}{\text { L }}$
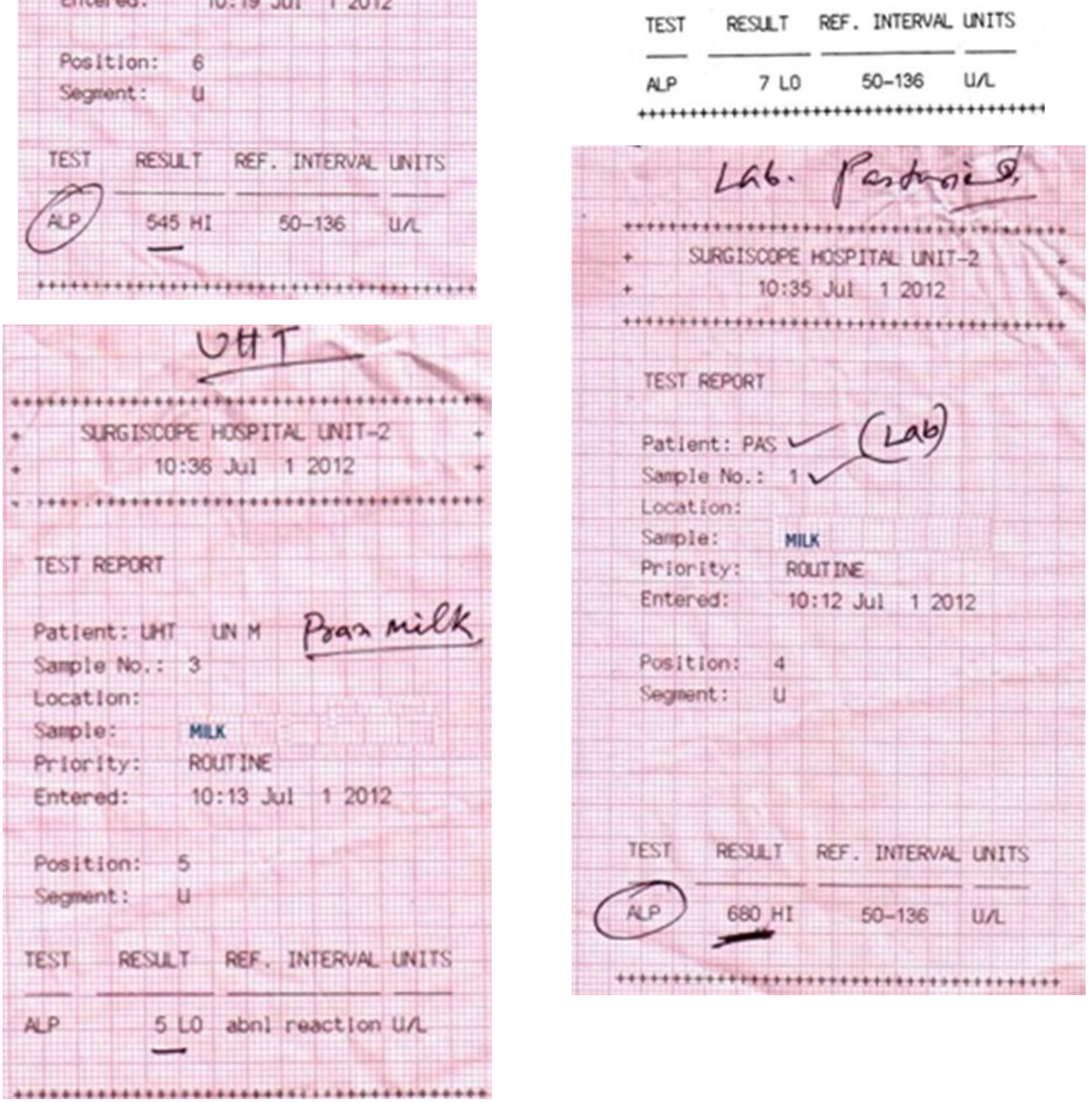

Volume 5 Issue 6, June 2016 www.ijsr.net

Licensed Under Creative Commons Attribution CC BY 
International Journal of Science and Research (IJSR)

ISSN (Online): 2319-7064

Index Copernicus Value (2013): 6.14 | Impact Factor (2015): 6.391

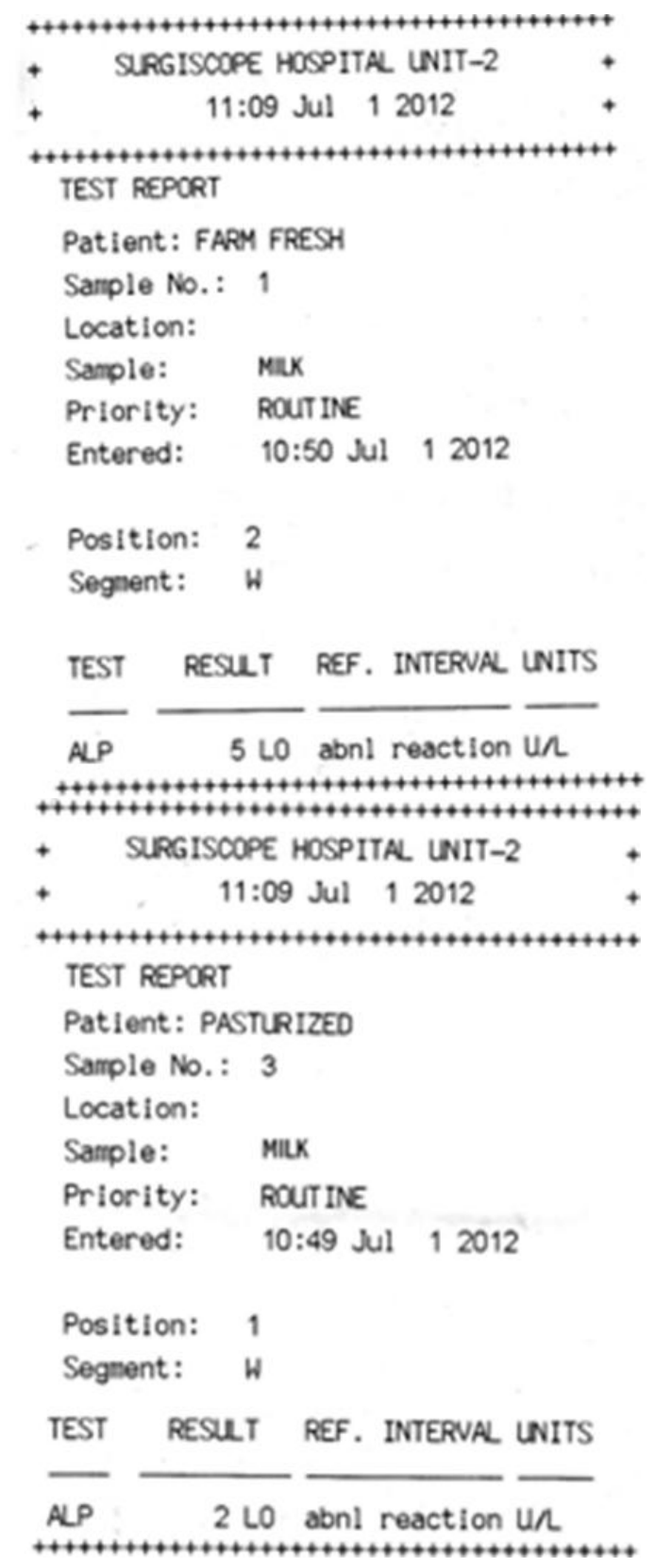

Experimental Procedure

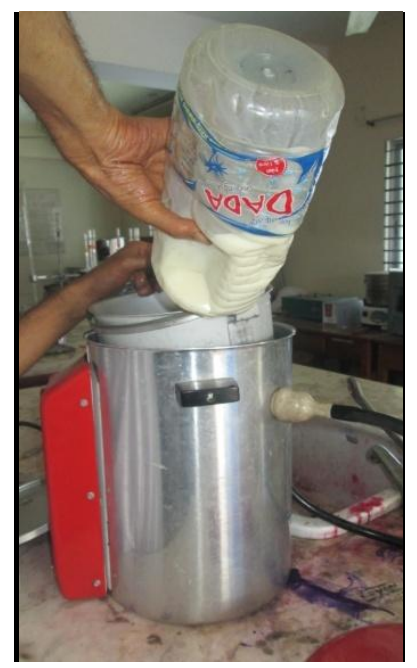

Figure 2.1: Pour on milk in Home Pasteurizer

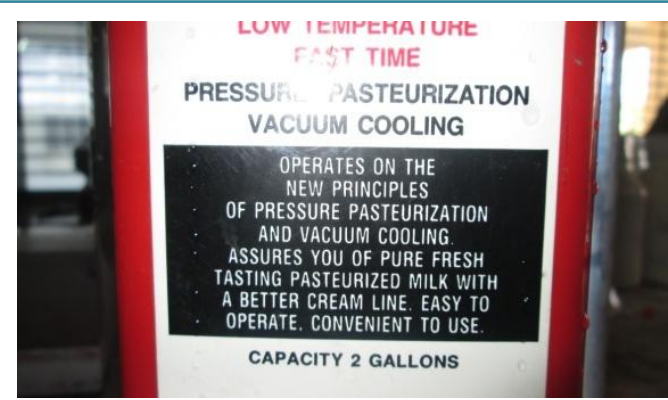

Figure 2.2: Indication

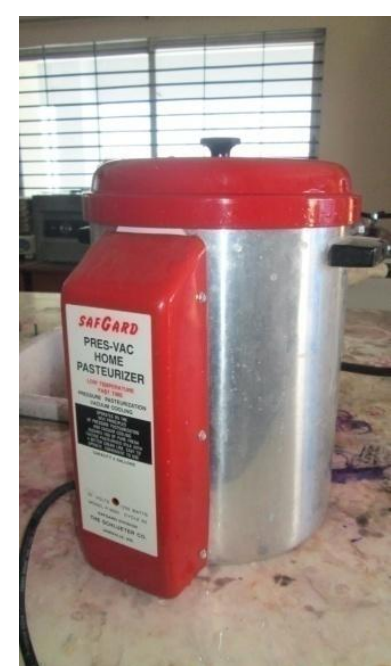

Figure 2.3: Pasteurization of Raw milk.

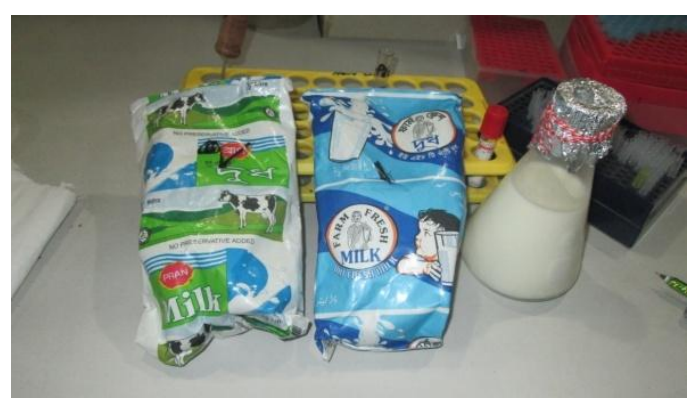

Figure 2.4: Samples

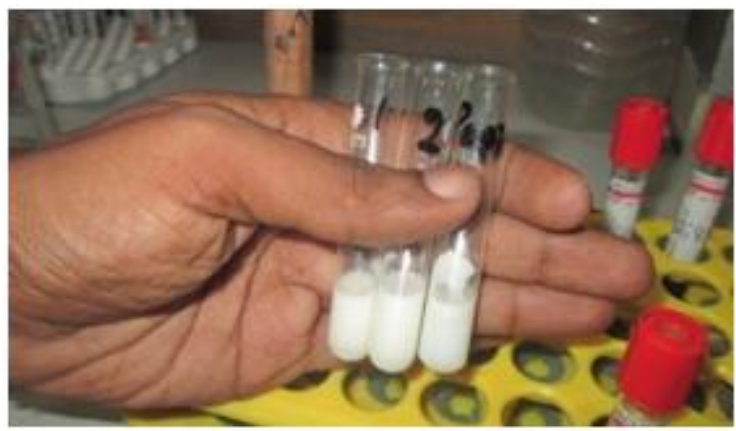

Figure 2.5: Synchronization of Samples

\title{
Volume 5 Issue 6, June 2016
}

\author{
www.ijsr.net
}

Licensed Under Creative Commons Attribution CC BY 


\section{International Journal of Science and Research (IJSR) \\ ISSN (Online): 2319-7064}

Index Copernicus Value (2013): 6.14 | Impact Factor (2015): 6.391

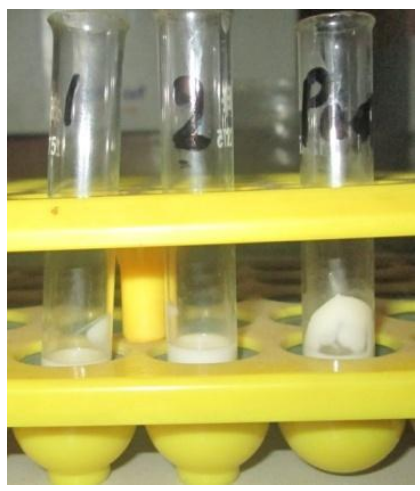

Figure 2.6: Samples for ALP analysis

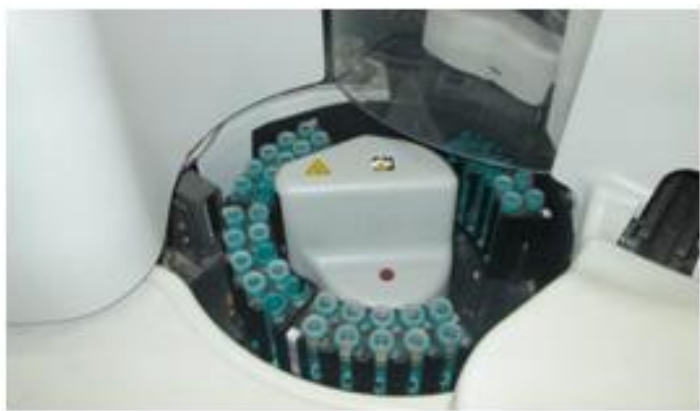

Figure 2.7: Samples setup for ALP analysis

\section{Conclusion}

Effective heat treatment of milk is essential to ensure the absence of pathogenic microorganisms and hence product safety for the shelf life of pasteurized milk. If the Alkaline Phosphatase originally present in Raw milk, then test negative following pasteurization, the analytical or production manager can be sure that the proper temperature and time control during processing has been used. Raw milk, Pasteurized milk and UHT milk must still test as Alkaline Phosphatase positive, otherwise these cannot be classified as such anymore. We may conclude that UHT pasteurized milk (Class-1) has a refrigerated shelf life of two to three weeks, whereas Home pasteurized milk (class-1,2) can last much longer when refrigerated, sometimes two to three months. When UHT treatment is combined with sterile handling and container technology (such as aseptic he proper packaging), it can even be stored unrefrigerated for 3-4 months. So in case of Research purpose Pasteurized milk from Home Pasteurizer and UHT milk of various types to identify Microbial loading under the ALP test. So DGKC Method is very much improved procedure than Conventional performance.

\section{References}

[1] Cunniff, P. 1995. $16^{\text {th }}$ Ed. Official method of Analysis: Association of Official Analytical Chemists. Washington DC.

[2] De Angelis, M., Di Cagno, R. Gallo, G. Curci, M. Siragusa, S., Crecchio, C., Parente, E. and Gobbetti, M 2007. International Journal of Food Microbiology 114: 69-82.
[3] Desbourdes,C.and Nicolas M.2008. Discussed about "Phosphatase activity in cheese" 11 th Workshop of the EURL for Milk and Milk Products.

[4] Eklund, C. and Lankford, C.E. 1967. Laboratory Manual for General Microbiology.Prentice Hall, Inc Englewood Cliffs, New Jersey, pp. 51-55.

[5] Fernandez-del-pozo,B., Gaya, P., Medina, M. Rodriguez-Marin, M.A., Nunez, M. and Fernandex-del, P.B. 1988. J. Dairy Res. 55(3): 449-455.

[6] Florez, A.B., Delgado, S. and Mayo, B. 2005. Antimicrobial susceptibility of lactic acid bacteria isolated from a cheese environment. Can. J. Microbiol. 51 (1): 51-58.

[7] Fox P.F. and Kelly A.L. 2006 showed that the use of alternative analytical methods is acceptable when the alkaline phosphatase determination methods are validated against the reference method in accordance with internationally accepted protocols in International Dairy Journal, 16, pp. 517-532.

[8] Frasier, W.C and Westhoff, D.C. 1988.Food Microbiology, $4^{\text {th }}$ ed.Tata Mc Graw Hill Publishing Company Limited.p.66.

[9] French, S.A. 2003. Pricing affects food choices.J Nutr133.841S-843S.

[10] French S.A., Harnack, L. nd Jeffery R. W 2000. Fast food restaurant use among women in Pound of Preventin study: dietary, behavioral and demographic correlates. J Obes Relat Metab Disord 24:1353-1359.

[11]Fratamico, P.M. and Bayles, D.O.(editor), 2005. Foodborne Pathogens: Microbiology and Moleculary Biology.Caister Academic Press. Faruque, S.M. (editor) 2012. Foodborne and Waterborne Baterial Pathogens: Epidemiology, Evolutin and Molecular Biology, Caister Academic Press.

[12]Franco, C. Quinto, E.,Rodriguez-otero, J.L., Fente, C. and Capeda, A. 1994. Microbiologycal Quality of cebrero from northwest Spain.J.Food safety. 14(1): 1-8.

[13] Grecz. N., Wagenaar, R.O. and Dack, G.M. 1965. Storage stability of clostridium botulinum toxin and spores in processed cheese. Appl. Microbiol. 13(6): 1014-1022.

[14] Greenwood, M.J.M.H and Pini, P.M. 1990. The occurrence of Listeria monocytogenes in cheese from a manufacturer associated with a case of listeriosis, Inter. J. Food Microbiol. 10(3-4): 255-262.

[15] Giraffa, G.2003.Functionality of Enterococci sp.in dairy products.Int.J. FoodMicrobiol. 88(2-3): 215-222.

[16] Gebhardt and Louis, P. 1970. "Microbiology" Fourth edn.The C.V. Mosby Company P: 159. 